\title{
SEASONAL BIOLOGY AND CONTROL OF THE DOGWOOD BORER, SYNANTHEDON SCITULA (LEPIDOPTERA: SESIIDAE) ON CLONAL APPLE ROOTSTOCKS IN NEW YORK
}

\author{
H. RiedL, R.W. Weires, A. SEAman, and S.A. Hoying \\ Department of Entomology, New York State Agricultural Experiment Station, Cornell University, Geneva, \\ New York, USA 14456
}

\begin{abstract}
Can. Ent. 117: 1367-1377 (1985)

The dogwood borer, Synanthedon scitula (Harris), is a relatively new pest problem on apples. Larvae feed principally in burr knots on the above-ground portion of clonal rootstocks. According to a survey of 33 orchards on dwarf or semidwarf apple rootstocks, about $70 \%$ of the trees had burr knots. The tendency to develop burr knots was similar among the rootstocks examined in this survey. The proportion of trees infested with dogwood borer in an orchard ranged from 0 to $100 \%$ and averaged $30 \%$. The dogwood borer overwinters in the larval stage (2nd to 6th instar) and pupates in the feeding tunnel. Emergence and pheromone-trap records indicate 1 generation a year. In western New York, adults begin to emerge in mid-June, peak in mid-July, and continue to emerge through September. In several tests conducted over a 3-year period, chlorpyrifos at $180 \mathrm{~g} / 100 \mathrm{~L}$ provided the most consistent control. At this rate a single spray timed to first or peak egg hatch was as effective as 2 sprays. Latex paint applied by brush to the trunk at the beginning of the oviposition period also reduced the infestation. In established plantings, dogwood borer can also be controlled by berming with soil up to the graft union to prevent access to burr knots. Destroying burr knots chemically with naphthalene acetic acid will not eliminate an infestation and may invite other borer problems.
\end{abstract}

\section{Résumé}

La sésie du cornouiller, Synanthedon scitula (Harris), constitue un problème relativement nouveau sur le pommier. Les larves se nourrissent surtout dans des bourrelets situés sur la partie hors terre de porte-greffes clonaux. D'après un inventaire effectué dans 33 vergers de porte-greffes nains et semi-nains de pommier, environ $70 \%$ des arbres avaient des bourrelets. La tendance au développement de ces bourrelets était similaire entre les souches de porte-greffes examinées lors de l'inventaire. La proportion des arbres infestés de sésie du cornouiller a varié de 0 à $100 \%$, avec une moyenne de $30 \%$. La sésie hiverne à l'état de larve (2ième au 6ième stade) et s'empupe dans la galerie d'alimentation. Des données d'émergence et de piégeage à la phéromone indiquent la présence d'une génération par an. Dans l'ouest de New York, les adultes commencent à émerger à la mi-juin, culminent à la mi-juillet et continuent à émerger en septembre. Des tests effectués sur une période de 3 ans ont montré que le chlorpyrifos à $180 \mathrm{~g} / 100 \mathrm{~L}$ a permis une répression satisfaisante. A cette concentration, un seul arrosage au début ou au pic d'éclosion des oeufs s'est avéré aussi efficace que 2 arrosages. On a aussi limité l'infestation en appliquant au pinceau de la peinture au latex sur le tronc au début de la période de ponte. On peut encore réprimer la sésie du cornouiller dans les plantations établies en renchaussant avec de la terre jusqu'à la jonction avec le greffon afin de prévenir l'accès aux bourrelets. La destruction chimique des bourrelets avec de l'acide naphthalèneacétique ne peut éliminer une infestation et pourrait susciter d'autres problèmes de perceurs.

\section{Introduction}

The dogwood borer, Synanthedon scitula (Harris), is a native clearwing moth with a wide host range. First recognized as a pecan pest (Pierce and Nickels 1941), it has become the most serious borer problem of ornamental dogwoods, Cornus florida L. (Underhill 1935; Wallace 1945; Potter and Timmons 1983). It has also been collected from a number of fruit and shade trees in which the larvae burrow under the bark, and often tunnel in galls and cankers (Engelhardt 1946). Although apple is a recorded host, 
the dogwood borer did not become an economic problem until the introduction of clonal apple rootstocks. There the larvae feed inside burr knots that can develop on the aboveground portion of Malling and Malling-Merton rootstocks. Burr knots are aggregations of partially developed root initials and usually develop below or at the graft union on the exposed portion of the rootstock (Rom and Brown 1979). In addition to harboring tree borers, burr knots are horticulturally objectionable because they can interfere with normal cambium growth and cause distortions of the trunk (Rom 1970).

About half of New York's apple acreage is now on size-controlling rootstocks of the Malling and Malling-Merton series (Anonymous 1980). In 1982, we initiated a survey to determine the extent of the burr-knot problem on dwarf and semidwarf rootstocks in the state and examine the borer infestations associated with them. At the same time, research was begun to document the seasonal activity of the dogwood borer on apple, describe its feeding behavior on this host, and develop chemical as well as cultural methods for its control in commercial orchards.

\section{Materials and Methods}

Orchard survey. In 1982 and 1983 a total of 33 orchards on the following clonal rootstocks of the Malling (M) and Malling-Merton (MM) series were surveyed: M.9, M.26, MM.106, MM.111, M.9 interstem on MM.106. The orchards ranged in age from 5 to 15 years and were situated in the main apple-production areas of western New York (Wayne, Ontario, Monroe, Orleans, and Niagara counties). About 40 trees were examined in each orchard. Data were taken on type of rootstock, scion variety, age of tree, height of graft union (HGU) above the soil line as a measure for rootstock exposure, burr knots (BKN) per tree, and infested burr knots per tree. Burr knots were classified as infested if frass was present on the surface.

Seasonal activity. Emergence records were taken at 2 locations. One was a heavily burrknotted "Empire" planting on M.9 and M.9/MM.111 rootstock located at the New York State Agricultural Experiment Station, Geneva. In May 1982, the lower trunk portions of 20 infested trees were caged with fiberglass screen. Trees were checked for emerged adults every 3-7 days. In 1983 and 1984, emergence was checked by inspecting infested trees for pupal skins protruding from burr knots. The second orchard where emergence was checked was a commercial planting of "Golden Delicious" on M.26 situated near Williamson (Wayne Co.). Trunks of 20 infested trees were caged in 1983. Cages were left in place for 2 years to determine if some individuals had a 2-year life cycle.

Monitoring with pheromone traps. In the same orchard where emergence records were taken at Geneva, adult activity was monitored with Pherocon ${ }^{\circledR} 1 \mathrm{CP}$ pheromone traps (Trece Co., Salinas, CA 93901). In early June, 3 traps were hung at eye level within the tree canopy and baited with commercially available peachtree-borer lures. We found in preliminary tests that commercial peachtree-borer lures containing $95 \%+$ pure $Z, Z$-ODDA (3,13-octadecadien-1-ol acetate) plus a small amount of the $E, Z$ isomer attracted a sufficient number of dogwood borers in the field to be useful for monitoring. Pherocon lures (red rubber septa) were used as bait in 1982; in subsequent years Scentry ${ }^{\circledR}$ clearwing-borer lures (micro-fiber type; Scentry Inc., Phoenix, AZ 85016) were employed because of greater effectiveness. Traps were checked daily until first catch and then at least once a week until the end of moth flight. Lures were changed every 6 weeks.

To determine optimal trap placement in the canopy, traps were installed in a tree at 3 elevations $(0.7,1.2$, and $2.4 \mathrm{~m})$. The treatments were replicated 3 times and were conducted in a "Red Delicious" orchard with an average tree height of $2.7 \mathrm{~m}$. Catches were recorded weekly through the season. 
Overwintering stage. In April 1984, 70 larvae were collected from burr knots before they resumed feeding and preserved in $70 \%$ ethanol. Larval instars were determined according to head capsule size (Wallace 1945).

Degree-day calculations. Heat units were calculated for 11 different base temperatures $\left(0\right.$ to $\left.10^{\circ} \mathrm{C}\right)$ from daily maximum-minimum temperatures recorded near the emergence site at Geneva following the method of Baskerville and Emin (1969). For each of 3 years (1982 to 1984) degree days were summed from 1 October until the beginning of emergence. Degree-day sums from 1 October until first trap catch were analyzed separately. The base temperature, which according to Amold (1959) yields the lowest coefficient of variation between years, is the appropriate threshold for the degree-day calculations. Potter and Timmons (1983) used the same method to determine the base temperature for S. scitula on dogwoods.

Chemical-control experiments. In 1982 and 1983, a 9-year-old high-density apple planting of "Red Delicious" and "McIntosh" on M.26 rootstock was treated with endosulfan, chlorpyrifos, fenvalerate, and a white latex paint - NAA (napthalene acetic acid) mixture. Check trees were left untreated. Because each orchard where control experiments were conducted bordered dogwood-borer habitat (wood lots or back yards), a randomized complete-block design was chosen to account for a possible gradient in the dogwood-borer's distribution in the treatment area. Sprays were applied on 5 August 1982 with a handgun sprayer operating at $1035 \mathrm{kPa}$. About $2 \mathrm{~L}$ of dilute spray was applied until run-off to the trunk of each tree from the base to the first scaffold level. The following year, rates of the chlorpyrifos and fenvalerate treatments were lowered to be more in line with label recommendations. Except for the paint-NAA treatment, sprays were reapplied on 15 August 1983. On 2 November 1983, treatment as well as check trees were examined for the presence of live larvae, fresh frass, cocoons, and pupal skins. The number of burr knots and their condition was also recorded.

Two chemical-control tests were conducted in 1983 to evaluate different timings, additional treatments, and lower rates than those tested in the first experiment. Test A was conducted in a 5-year-old "Red Delicious" high-density planting on M.9 situated near Alton (Wayne Co.). This test included 7 insecticide treatments, 2 latex-paint treatments, and an untreated check. Each treatment consisted of 320 -tree replicates arranged in a randomized complete block. Treatments were applied only once, on 30 June 1983, about 2 weeks after emergence of dogwood borer was first detected in the area. Because eggs hatch in 8-9 days (Underhill 1935), a 2-week interval was chosen to approximate the combined pre-oviposition and incubation period. Sprays were applied with a backpack sprayer operated by handpump. About $0.2 \mathrm{~L}$ of spray was applied to the lower trunk of each tree. Treatments were evaluated in June 1984, prior to larval hatch of the 1984 flight. Test B was conducted in a mixed planting of "Mutsu", "Idared", and "Cortland" on MM.106 near Williamson (Wayne Co.) and included 4 insecticide treatments, 1 paint treatment, and an untreated check. Each treatment consisted of 3 14-tree replicates arranged in a randomized complete-block design. Sprays were applied on 2 August 1984, about 2 weeks after peak emergence in the area.

The purpose of the 1984 test was to evaluate further the treatment timings and to compare 1 versus 2 spray applications. The first 2 treatments were applied as single sprays on 6 July and 7 August, respectively. The third treatment included 2 sprays, one of which was applied on each of those dates. The July spray was timed to first egg hatch, about 2 weeks after first emergence. The August spray was applied when egg hatch peaked about 2 weeks after peak emergence. This experiment was conducted in a "Red Delicious" planting adjacent to the 1983 test plot (test A). The lower tree trunks were sprayed as in 1983. Treatments consisted of 3 15-tree replicates arranged in a randomized completeblock design; they were evaluated 2 November 1984. 
Table 1. Dogwood-borer survey: summary for 8 orchards in western New York

\begin{tabular}{|c|c|c|c|c|c|c|}
\hline Rootstock & Scion & $\begin{array}{c}\text { Age } \\
\text { (years) }\end{array}$ & $\begin{array}{c}\text { Mean HGU* } \\
(\mathrm{cm}) \\
( \pm \mathrm{SE}) \\
\end{array}$ & $\begin{array}{c}\text { Mean no. } \\
\text { burr knots } \\
\text { tree }( \pm \mathrm{SE})\end{array}$ & $\begin{array}{c}\text { Mean } \\
\text { infested } \\
\text { burr knots/ } \\
\text { tree }( \pm \mathrm{SE})\end{array}$ & $\begin{array}{c}\% \text { trees } \\
\text { infested }\end{array}$ \\
\hline \multirow[t]{2}{*}{ M.9 } & Golden Delicious & & & & & \\
\hline & Spartan & 7 & $19.1( \pm 0.81)$ & $3.71( \pm 0.25)$ & $2.08( \pm 0.25)$ & 76 \\
\hline M.9 & Empire & 9 & $5.6( \pm 0.81)$ & $0.60( \pm 0.19)$ & $0.15( \pm 0.07)$ & 13 \\
\hline M.26 & McIntosh & 11 & $11.7( \pm 1.18)$ & $2.50( \pm 0.36)$ & $2.00( \pm 0.29)$ & 85 \\
\hline M.26 & Golden Delicious & 15 & $11.5( \pm 0.96)$ & $0.38( \pm 0.11)$ & $0.13( \pm 0.06)$ & 10 \\
\hline MM.106 & Idared & 9 & $24.1( \pm 0.73)$ & $6.35( \pm 0.58)$ & $4.00( \pm 0.46)$ & 78 \\
\hline MM.106 & Rome & 13 & $14.6( \pm 0.65)$ & $2.38( \pm 0.21)$ & $0.11( \pm 0.09)$ & 4 \\
\hline MM.111 & McIntosh & 8 & $3.9( \pm 0.73)$ & $3.11( \pm 0.50)$ & $0.07( \pm 0.07)$ & 2 \\
\hline MM.111 & Idared & 5 & $17.1( \pm 0.88)$ & $1.62( \pm 0.21)$ & $0.18( \pm 0.07)$ & 13 \\
\hline
\end{tabular}

*HGU $=$ height of the graft union above the soil line.

All control experiments were analyzed by a two-way analysis of variance. Treatment means were ranked using Waller-Duncan's (1969) Bayesian significant difference (BSD) rule at $P<0.05$.

Cultural-control experiments. The effect of burying the exposed portion of the rootstock was demonstrated in a heavily burr-knotted "Empire" planting on M.26 with a moderate infestation level. The average number of burr knots per tree was $4.2 ; 0.9$ of those showed evidence of borer feeding. In the spring of 1983, soil was mounded around the trunks of 20 trees up to the graft union. The average height of the graft union was $8.1 \mathrm{~cm}$ with a range from 1.5 to $17.5 \mathrm{~cm}$. In addition, trunks were caged with fiberglass screen to determine dogwood-borer emergence from the buried rootstocks. Cages were checked every 3 weeks for adults. In the fall the soil around the buried rootstocks was removed to examine root growth from the burr knots.

\section{Results}

Orchard survey. Table 1 gives a summary of burr-knot incidence and infestation levels for 2 representative orchards on each of 4 rootstocks. There was considerable variability in rootstock exposure (HGU), number of burr knots per tree, and infestation levels between orchards on the same rootstock (Table 1). Even within orchards on the same rootstock, planting depth was often very non-uniform as indicated by the standard error associated with the HGU measurement.

In every orchard where part of the rootstock was exposed, burr knots were present. In about $2 / 3$ of the orchards surveyed, the number of burr knots per tree increased with the amount of rootstock exposure (HGU). Regression analyses indicated a positive linear relationship between burr knots per tree and the HGU measurement for 20 of the 33 orchards $(P<0.05)$. $R^{2}$ values for significant regressions ranged from 0.07 to 0.67 and averaged 0.30 . Burr-knot incidence was similar on the rootstocks and rootstock/interstem combinations examined in this survey (Table 2). Also, there was no significant difference in the number of burr knots per tree among the various rootstocks. On average, about $70 \%$ of the apple trees surveyed had burr knots.

Approximately $30 \%$ of the apple trees on clonal rootstock in western New York were infested with dogwood borer. Infestation levels for individual blocks ranged from 0 to $100 \%$. We observed large differences in infestation levels not only between rootstocks but also among orchards on the same rootstock (Tables 1 and 2). The rootstock MM.111, although similar to other rootstocks in terms of burr-knot incidence, had a significantly lower infestation. 
Table 2. Dogwood-borer survey: summary by rootstock

\begin{tabular}{lcccc}
\hline & $\begin{array}{c}\text { No. } \\
\text { blocks } \\
\text { surveyed }\end{array}$ & $\begin{array}{c}\text { Mean } \% \\
\text { trees with } \\
\text { burr knots }( \pm \mathrm{SE})^{*}\end{array}$ & $\begin{array}{c}\text { Mean \% } \\
\text { trees } \\
\text { infested } \\
( \pm \mathrm{SE})^{*}\end{array}$ & $\begin{array}{c}\text { Mean no. } \\
\text { burr knots/ } \\
\text { tree }( \pm \mathrm{SE})^{*}\end{array}$ \\
\hline M.9 & 6 & $74( \pm 10.6)$ n.s. & $35( \pm 11.7) \mathrm{a}$ & $2.2( \pm 0.5) \mathrm{n.s}$. \\
M.9/MM.106 & 4 & $76( \pm 9.2)$ & $32( \pm 14.8) \mathrm{a}$ & $2.4( \pm 1.1)$ \\
M.26 & 10 & $73( \pm 7.7)$ & $37( \pm 11.0) \mathrm{a}$ & $2.3( \pm 0.4)$ \\
MM.106 & 8 & $68( \pm 11.9)$ & $35( \pm 13.6) \mathrm{a}$ & $3.8( \pm 1.0)$ \\
MM.111 & 5 & $69( \pm 7.8)$ & $4( \pm 2.4) \mathrm{b}$ & $2.0( \pm 1.1)$ \\
\hline
\end{tabular}

* Means followed by the same letter are not significantly different according to a $\chi^{2}$ test $(P<0.01)$; n.s. = not significant.

Seasonal activity on apple in New York. The dogwood borer overwinters as a larva in the burr-knot tissue. A sample of hibernating larvae included instars 2 to 6 in the following proportions: $2,11.6 \% ; 3,29.0 \% ; 4,37.7 \% ; 5,18.8 \% ; 6,2.9 \%$. It is likely that the younger instars were underrepresented in this sample because they are more easily overlooked or inadvertently crushed due to their small size. These data suggest that most larvae overwinter as 3rd, 4th, and 5th instars.

Mature larvae pupate in the feeding tunnel inside a silken cocoon covered with pieces of frass. Just prior to adult emergence, the pupa pushes through the cocoon to the surface of the burr knot. The amber-colored pupal skins can often be found protruding from infested burr knots and can stay on the tree for several months. The pattern of emergence was similar during 3 years of observations at Geneva (Fig. 1, closed circles). Emergence was observed over a 3-month period beginning about mid-June, peaking in mid-July, and continuing through September. The unimodal emergence pattern suggests a single generation in western New York.

Some larvae may require 2 years to complete development in the Geneva area. Dogwood borer infested M.26 rootstocks caged for 2 successive years produced 64 adults in 1983 and 4 adults in 1984. Because the cages prevented oviposition in 1983, we assume that these 4 adults developed from larvae that hatched late in 1982 and that did not transform to adults in 1983. More observations are necessary to confirm whether some larvae overwinter twice.

Records of flight activity obtained with pheromone traps corresponded closely to emergence (Fig. 1, open circles). Three years of trapping indicated a distinct main flight period in June and July. In 1982 and 1984, the main flight peak was followed by extended activity in late August and September (Fig. 1).

A lower threshold for the degree-day calculations could not be determined from the data because the coefficient of variation $(\mathrm{CV})$ never reached a pronounced minimum at any of the 11 base temperatures tested. The CV decreased from the high to the low base temperatures until it levelled off below $5^{\circ} \mathrm{C}$. Differences in the CV's between 0 and $5^{\circ} \mathrm{C}$ were very small. This suggests that the appropriate base temperature is probably in that range. A base temperature of $4^{\circ} \mathrm{C}$ was chosen for subsequent calculations to permit comparisons with the degree-day sums of Potter and Timmons (1983). The dates and degreeday accumulations (base $4^{\circ} \mathrm{C}$ ) for the beginning and medians of emergence and trap catch are given in Table 3. The average degree-day sums for corresponding phenological events (e.g. first catch and first emergence) were similar but had large SE's. By comparison, the average dates appeared to be less variable and better predictors of emergence and trap catch than temperature sums.

The Pherocon peachtree-borer-pheromone lures performed well in 1982 but for unknown reasons were less effective than the Scentry clearwing-moth lures (micro-fiber type) in 1983 and 1984 . The following sesiid species were consistently captured with these 

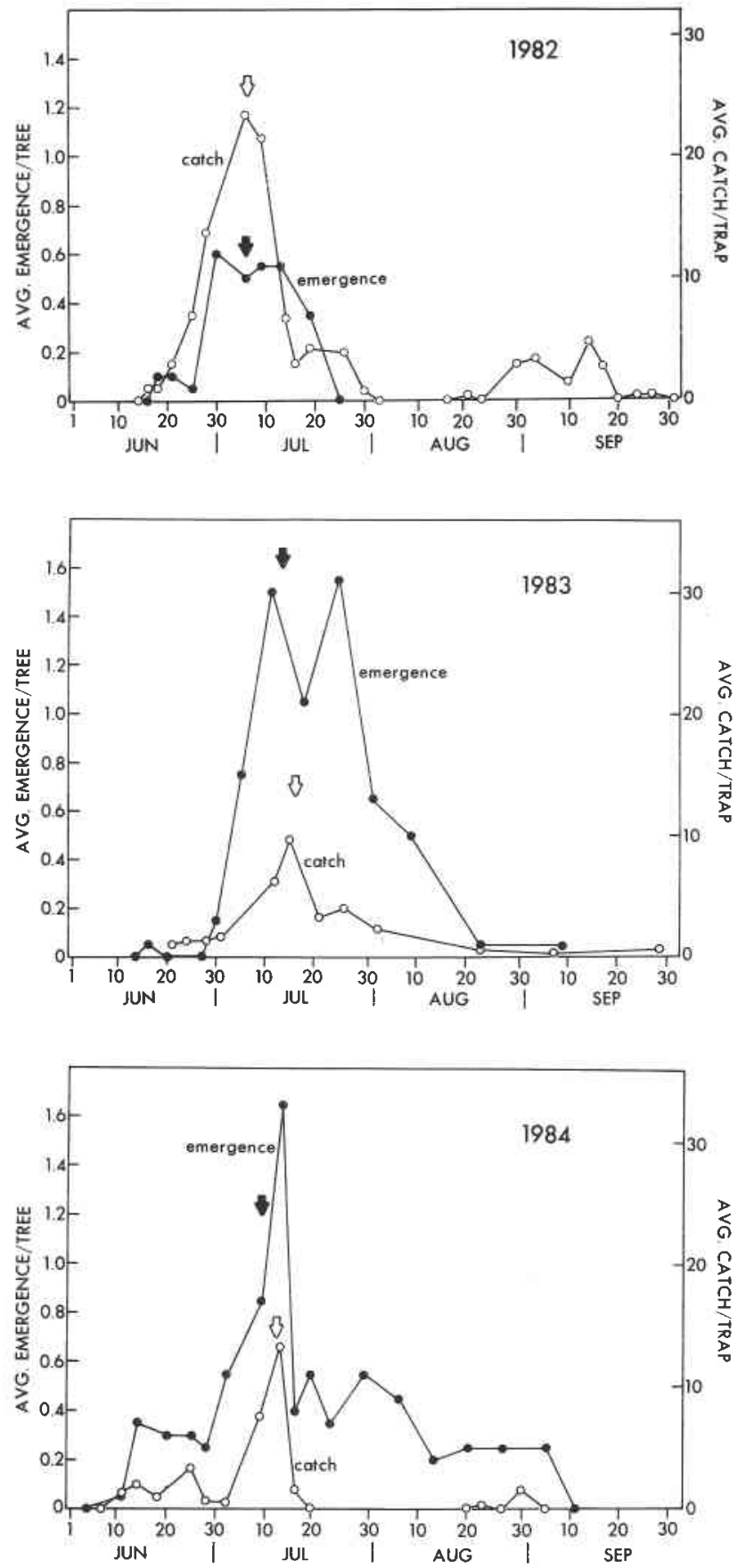

Fig. I. Emergence of dogwood borer and pheromone-trap catches in a dwarf-apple planting at Geneva, New York, over a 3-year period (1982-1984); arrows indicate the median dates. 
Table 3: Dates and degree-day* accumulations from 1 October for phenological events of Synanthedon scitula

\begin{tabular}{|c|c|c|c|c|c|c|c|c|c|}
\hline \multirow[b]{2}{*}{ Year } & \multicolumn{2}{|c|}{ First emergence } & \multicolumn{3}{|c|}{ First catch $\dagger$} & \multicolumn{2}{|c|}{$50 \%$ emergence } & \multicolumn{2}{|c|}{$50 \%$ catch $\dagger$} \\
\hline & Date & ${ }^{\circ} \mathrm{D}$ & & Date & ${ }^{\circ} \mathrm{D}$ & Date & ${ }^{\circ} \mathrm{D}$ & Date & ${ }^{\circ} \mathrm{D}$ \\
\hline 1982 & 18 June & 961 & 16 & June & 935 & 6 July & 1208 & 6 July & 1209 \\
\hline 1983 & 16 & 1026 & 21 & & 1113 & 16 & 1556 & 13 & 1489 \\
\hline 1984 & 11 & 872 & 11 & & 872 & 12 & 1347 & 9 & 1303 \\
\hline Average & 15 & 953 & 16 & & 973 & 11 & 1370 & 9 & 1334 \\
\hline SE & 2 & 45 & 3 & & 72 & 3 & 101 & 2 & 82 \\
\hline
\end{tabular}

*Base $4^{\circ} \mathrm{C}$

IIn pheromone-baited traps.

lures: peachtree borer, S. exitiosa (Say); dogwood borer, S. scitula (Harris); lilac borer, Podosesia syringae (Harris); and maple callus borer, S. acerni (Clemens). Catches of dogwood borer with the clearwing-moth lure can be maximized by placing traps at $1.2 \mathrm{~m}$ height in trees. Weekly catches per trap averaged 1.25 moths $( \pm 0.95 \mathrm{SE})$ at $0.7 \mathrm{~m}, 5.25$ moths $( \pm 1.65)$ at $1.2 \mathrm{~m}$, and 0.75 moths $( \pm 0.25)$ at $2.4 \mathrm{~m}$ in apple trees $2.7 \mathrm{~m}$ tall. Traps at $1.2 \mathrm{~m}$ in the lower canopy caught a significantly larger number of moths than traps at the other 2 elevations; there was no significant difference in catches between traps at 0.7 and $2.4 \mathrm{~m}$ [Waller-Duncan's (1969) BSD rule at $P<0.05$ ].

Feeding activity on clonal rootstocks. We recognized 3 types of feeding: in the burrknot tissue itself, in the cambium at the periphery of the burr knot, and short tunnels below the bark outside burr knots. The initial point of entry is usually the burr knot. The newly hatched larvae bore into the tissue between the root initials where they commence feeding. The rough texture of the burr knot's exterior may stimulate larval attack. Also, burr knots consist primarily of meristematic, non-lignified root tissue that larvae can easily penetrate. When larvae are in the 1st and 2nd instar it is difficult to detect whether a burr knot is infested or not. As larvae grow, and as they increase their feeding activity, they begin to push easily visible reddish frass to the surface. The tunnels in newly infested burr knots are irregular, not well defined, and quite shallow: If reinfestation occurs, larvae will penetrate deeper into the burr knot to feed on the live tissue. Because of the shallow feeding, the tunnel created by one larva can extend over a large area of the burr knot. In orchards with heavy infestations, 10 or more larvae in large-sized burr knots were not uncommon.

If the burr knot is destroyed by successive larval infestations, larvae often begin to feed in the cambium at the periphery of the burr knot. For instance, in a sample of 127 infested burr knots 21 or $16.5 \%$ showed evidence of feeding in the adjoining cambium. On occasion, young larvae begin to feed outside burr knots under large bark scales and where the bark is rough and cracking. These attacks are not common on clonal rootstocks. Short feeding tunnels outside burr knots above and below the graft union were found more frequently on trees whose lower trunk was tightly wrapped with a plastic mouse guard.

Chemical control of dogwood borer. In the 1982 tests, the number of burr knots per tree was lower in the paint-NAA treatment than in the untreated check or other treatments (Table 4). However, the difference was not large enough to affect the outcome of the experiment. All trunk applications of insecticides reduced the infestation below the check and provided economic control. The paint-NAA treatment, which was not reapplied in 1983, killed the burr knots, but had no effect on the borer infestation. Killing the burrknot tissue with NAA may not be desirable because it forces larvae to feed at the periphery of the burr knot in the healthy cambium. Because the paint as well as the other treatments were applied in August, it required considerable care to prevent drift to fruit on lowhanging limbs. 
Table 4. Control of dogwood borer by trunk applications on M.26 rootstock; Valatie, New York, 1982 and 1983

\begin{tabular}{|c|c|c|c|c|c|}
\hline \multirow{2}{*}{$\begin{array}{l}\text { Treatments } \\
\text { (materials and } \\
\text { formulation) }\end{array}$} & \multirow{2}{*}{$\begin{array}{c}\text { Rate } \\
\text { (grams AI } \\
100 \mathrm{~L} \text { ) }\end{array}$} & \multicolumn{2}{|c|}{$\begin{array}{c}\text { Time of } \\
\text { application }\end{array}$} & \multirow{2}{*}{$\begin{array}{c}\text { Mean no. } \\
\text { burr knots } \\
\text { tree* }\end{array}$} & \multirow{2}{*}{$\begin{array}{c}\text { Mean no. new } \\
\text { infestations } \\
\text { tree, }\end{array}$} \\
\hline & & $\begin{array}{c}5 \text { Aug. } \\
1982\end{array}$ & $\begin{array}{c}15 \text { Aug. } \\
1983\end{array}$ & & \\
\hline Endosulfan 50\% WP & 90 & $\mathrm{X}$ & $\mathrm{X}$ & $2.2 \mathbf{a}$ & $0.14 \mathrm{~b}$ \\
\hline $\begin{array}{l}\text { Chlorpyrifos } 4 \mathrm{EC} \\
\text { Chlorpyrifos } 50 \% \text { WP }\end{array}$ & $\begin{array}{l}400 \\
180\end{array}$ & $\mathrm{X}$ & $\mathrm{x}$ & $2.5 \mathrm{a}$ & $0.04 b$ \\
\hline Fenvalerate $2.4 \mathrm{EC}$ & $\begin{array}{r}45 \\
9\end{array}$ & $\mathrm{X}$ & $\mathrm{x}$ & $2.5 \mathrm{a}$ & $0.10 \mathrm{~b}$ \\
\hline $\begin{array}{l}\text { White latex paint } \$ \\
\text { plus } \\
\text { NAA } 12 \% \S\end{array}$ & & $\mathrm{X}$ & & $1.5 b$ & $0.71 \mathrm{a}$ \\
\hline Untreated check & & & & $2.1 \mathrm{ab}$ & $0.94 a$ \\
\hline
\end{tabular}

*Means in each column not followed by the same letter are significantly different according to Waller-Duncan's (1969) BSD rule $(P<0.05)$.

tLive larvae and fresh empty cocoons combined; evaluated 2 Nov. 1983.

†Diluted 1:2 (paint:water).

$\S N A A=$ naphthalene acetic acid; $3.5 \mathrm{~L} / 100 \mathrm{~L}$ of paint-water mixture.

In the 1983 tests (Table 5) single sprays of chlorpyrifos, methylparathion, and endosulfan applied at first (test A) or peak (test B) egg hatch significantly reduced the borer infestation. Fenvalerate at $9 \mathrm{~g} \mathrm{AJ} / 100 \mathrm{~L}$ was not as effective as the higher rate of chlorpyrifos in the earlier test but was equal to the other insecticide treatments in test B. Undiluted white latex paint applied by brush to infested rootstocks (test A) provided surprisingly good control comparable to most insecticide treatments in the test. Control was slightly weaker when the paint was diluted 1:2 with water and sprayed on. Painting exposed rootstocks with white latex in early August at the time of peak egg hatch (test B) appeared to be less effective; the infestation was not significantly different from the untreated check.

Table 5. Control of dogwood borer on clonal apple rootstocks by single trunk applications of several insecticides and white latex paint timed to first (test A) and peak (test B) egg hatch; Wayne Co., New York, 1983

\begin{tabular}{|c|c|c|c|c|c|}
\hline \multirow[b]{2}{*}{$\begin{array}{l}\text { Treatments } \\
\text { (materials and } \\
\text { formulation) }\end{array}$} & \multirow[b]{2}{*}{$\begin{array}{c}\text { Rate } \\
\text { (grams AI } \\
100 \mathrm{~L} \text { ) }\end{array}$} & \multicolumn{2}{|c|}{ Test $A^{*}$} & \multicolumn{2}{|c|}{ Test $\mathrm{B} \dagger$} \\
\hline & & $\begin{array}{c}\text { Mean no. } \\
\text { burr knots/ } \\
\text { tree }+\end{array}$ & $\begin{array}{c}\text { Mean no. new } \\
\text { infestations/ } \\
\text { tree }\end{array}$ & $\begin{array}{l}\text { Mean no. } \\
\text { burr knots/ } \\
\text { tree } \neq\end{array}$ & $\begin{array}{c}\text { Mean no. new } \\
\text { infestations/ } \\
\text { tree }\end{array}$ \\
\hline \multirow[t]{2}{*}{ Chlorpyrifos $50 \%$ WP } & 180 & 1.75 n.s. & $0.16 \mathrm{~d}$ & & \\
\hline & 90 & 1.98 & $0.40 \mathrm{~cd}$ & & \\
\hline \multirow[t]{2}{*}{ Chlorpyrifos $4 \mathrm{EC}$} & 180 & 1.85 & $0.19 \mathrm{~d}$ & $3.83 \mathrm{ab}$ & $0.03 \mathrm{c}$ \\
\hline & 90 & 1.77 & $0.46 \mathrm{~cd}$ & & \\
\hline \multicolumn{6}{|l|}{ Methyl-parathion 2 FM } \\
\hline (microencapsulated) & 60 & 1.40 & $0.43 \mathrm{~cd}$ & $2.55 \mathrm{~b}$ & $0.24 \mathrm{abc}$ \\
\hline Endosulfan $50 \%$ WP & 90 & 1.23 & $0.61 \mathrm{bcd}$ & $3.20 \mathrm{ab}$ & $0.11 \mathrm{bc}$ \\
\hline Fenvalerate $2.4 \mathrm{EC}$ & 9 & 1.52 & $0.63 b c$ & $4.66 a$ & $0.15 b c$ \\
\hline White latex (brushed) & Undiluted & 1.52 & $0.64 b c$ & & \\
\hline White latex (brushed) & Diluted 1:1\| & & & $3.49 \mathrm{ab}$ & $0.34 a b$ \\
\hline White latex (sprayed) & Diluted $1: 2 \|$ & 1.70 & $1.00 \mathrm{~b}$ & & \\
\hline Untreated check & & 1.78 & $1.68 \mathrm{a}$ & $4.54 \mathrm{a}$ & $0.76 a$ \\
\hline
\end{tabular}

*Applied 30 June 1983; evaluated May 1984

$\dagger$ Applied 2 Aug. 1983; evaluated June 1984.

$\ddagger$ Means in each column not followed by the same letter are significantly different according to Waller-Duncan’s (1969) BSD rule $(P<0.05) ; \mathrm{n} . \mathrm{s} .=$ not significant

$\S$ Live larvae, pupae, and fresh cocoons.

॥Paint:water. 
Table 6. Evaluation of timing and the number of applications of chlorpyrifos for control of dogwood borer on M.9 rootstock; Wayne Co., New York, 1984

\begin{tabular}{|c|c|c|c|c|}
\hline \multirow{2}{*}{$\begin{array}{l}\text { Treatments } \\
\text { (material and } \\
\text { formulation) }\end{array}$} & \multicolumn{2}{|c|}{$\begin{array}{c}\text { Time of } \\
\text { application }\end{array}$} & \multirow{2}{*}{$\begin{array}{l}\text { Mean no. } \\
\text { burr knots/tree } \dagger\end{array}$} & \multirow{2}{*}{$\begin{array}{c}\text { Mean no. new } \\
\text { infestations/ } \\
\text { tree }^{+\neq}\end{array}$} \\
\hline & 6 July & 7 Aug. & & \\
\hline Chlorpyrifos $4 \mathrm{EC}^{*}$ & $X$ & & 2.53 n.s. & $0.00 \mathrm{~b}$ \\
\hline Same & & $\mathrm{X}$ & 2.78 & $0.00 \mathrm{~b}$ \\
\hline Same & $\mathrm{X}$ & $\mathrm{X}$ & 2.98 & $0.04 b$ \\
\hline Untreated check & & & 2.59 & $1.25 \mathrm{a}$ \\
\hline
\end{tabular}

*Applied at 180 grams AV/100 L.

$\dagger$ Means in each column not followed by the same letter are significantly different according to Waller-Duncan's (1969) BSD rule $(P<0.05) ; \mathrm{n} . \mathrm{s} .=$ not significant.

thive larvae, pupae, and fresh cocoons; evaluated 24 Oct, 1984

In 1984 we compared timing and 1 versus 2 applications using only chlorpyrifos 4 EC (Table 6). Single trunk sprays applied either in early July at the beginning of egg hatch or in early August at peak egg hatch were as effective as 2 sprays.

Control of burr knots. NAA applied to the above-ground portion of the rootstock destroyed the burr knots. However, as shown in Table 4, this did not discourage attack by the dogwood borer. When soil was mounded around the exposed portion of M.26 rootstocks in the spring, healthy uninfested burr knots developed strong roots over the summer. Root development from infested burr knots with most of the root initials destroyed by borer feeding was poor. The additional root growth improved anchorage of the trees. Burying the rootstocks with soil prevented any successful borer emergence and prevented any further infestations.

\section{Discussion}

There is considerable potential for infestations by the dogwood borer on apple in New York inasmuch as more than $40 \%$ of the state's apple acreage is now on clonal rootstocks (Anonymous 1980). All commercial dwarfing and semidwarfing rootstocks have a tendency to develop burr knots and are, therefore, prone to attack by this borer. About $1 / 3$ of all apple trees on clonal rootstocks were found to be infested in western New York. Infestation levels could rise further because of the high incidence of burr knots in commercial orchards. Among several Malling and Malling-Merton rootstocks, only MM.111 had a significantly lower infestation. It is not clear at this point whether this is a characteristic of the rootstock and indicates non-preference. The lower infestation levels on MM.111 could also be due to the variability in the distribution of the dogwood borer between orchards and the relatively small number of orchards surveyed.

The dogwood borer emerges from apple in western New York from mid-June into September. By comparison, emergence from dogwood in Tennessee begins in late April, peaks in mid-May, and continues until September (Pless and Stanley 1967). Further north in Connecticut, S. scitula emerges from dogwood in late May through September with peak activity during late June and early July (Wallace 1945). Because of similar climate and geographic proximity, emergence of dogwood borer in the apple-growing areas of eastern New York (lower Hudson Valley) is probably close to that described for Connecticut. Throughout its range, S. scitula is reportedly univoltine (Underhill 1935; Pless and Stanley 1967; Potter and Timmons 1983). In New York, S. scitula is also univoltine. However, some individuals may require 2 years to eclose. Synanthedon myopaeformis Brkh., a closely related European sesiid with similar feeding habits, can have a 1or 2-year life cycle on apple. When it feeds in burr knots it is primarily univoltine (Dickler 1976). Using pheromone traps, Potter and Timmons (1983) noted 2 distinct flight peaks 
in Kentucky, one in late May and the other in August. Because pupal collections did not indicate bivoltinism, they suggested that the bimodal flight pattern was created by host populations that emerge at different times of the season. Our degree-day totals from 1 October until the beginning and median of trap catch the following year were considerably lower than the values reported by Potter and Timmons (1983) for S. scitula on dogwoods. At Geneva the 3-year average for first moth catch was 973 degree-days as compared with 1256 and 1286 in Kentucky. The difference may be related to the different hosts on which these populations developed.

The peachtree-borer pheromone is attractive to the dogwood borer and can be used for monitoring. Ninety-nine percent plus pure Z,Z-ODDA would be a more specific and effective attractant for S. scitula according to Potter and Timmons (1983) but is not commercially available.

On dogwoods, larvae generally enter through small wounds or cracked callus growth and rarely bore through the healthy bark (Wallace 1945; Pless and Stanley 1967). Similarly, on pecans, larvae begin to feed at points of injury such as fresh grafts (Pierce and Nickels 1941). On clonal rootstocks, injured tissue is not a prerequisite for attack by the dogwood borer. Healthy, actively growing burr knots will be attacked as soon as they develop on the rootstock. On ornamental dogwoods nearly mature larvae may leave their gallery and construct short new tunnels up to $75 \mathrm{~cm}$ away from the original feeding site (Wallace 1945). The same can occur on clonal rootstocks especially when infestation levels are high or when the lower trunks are wrapped with tight-fitting plastic mouse guards. If mouse guards trap moisture and prevent the trunk from drying, conditions are created that favor larval survival and allow larvae to migrate without the danger of desiccating.

A single larva can girdle a dogwood tree in 1 year. More often, however, tree death is the result of multiple infestations over successive years (Wallace 1945). It appears that the effect of dogwood-borer feeding on the rootstock of dwarf apple trees is not immediate because infestations are initially localized in the burr knots and only slowly spread into the healthy cambium tissue. Though not common, tree kills attributable to dogwood-borer feeding do occur. Although precise information on the relationship between rootstock infestations and yield is presently not available for $S$. scitula, data on S. myopaeformis, which occupies a similar niche in Europe, suggest that burr-knot feeding can result in a yield reduction of up to $20 \%$ on some varieties (Dickler 1976).

In all 3 field tests, both formulations of chlorpyrifos tended to give better control than other treatments. It should be pointed out, however, that the rates of chlorpyrifos were somewhat higher than those of other insecticides used in the tests. If $1 \mathrm{~L}$ of dilute spray was applied to each rootstock, up to 934 trees per hectare could be sprayed with chlorpyrifos at $180 \mathrm{~g}$ per $100 \mathrm{~L}$ without exceeding the maximum label rate per hectare. Rates of the other insecticides could be doubled to improve efficacy because they are well below the maximum allowable per hectare according to current labels. Single applications of chlorpyrifos, lindane, and endosulfan provided good control of S. scitula on ornamental dogwoods in Kentucky (Potter and Timmons 1983). White latex paint applied to the trunk can also provide a measure of protection against dogwood-borer attack. How the paint protects the tree was not investigated. It may simply mask potential oviposition and feeding sites, thus discouraging oviposition and larval penetration into the burr-knot tissue. Paint treatments without any addition of insecticides have also been shown to reduce attack of lesser peachtree borer, $S$. pictipes (Grote and Robinson), and American plum borer, Euzophera semifuneralis (Walker), on tart cherries (Wiener 1982).

Our tests indicate that timing of trunk sprays may not be as crucial for dogwoodborer control as for other borer problems on fruit trees. The timing in the 1982 control test was not optimal because sprays were applied from 10 to 20 days after peak egg hatch in the area. However, in spite of poor timing, control was good, possibly due to penetration 
of the spray into the spongy burr-knot tissue and the relatively shallow feeding of the larvae. The 1983 and 1984 tests showed that dogwood borer on clonal rootstocks can be controlled with a single trunk application and that sprays timed to first or peak egg hatch are equally effective. Potter and Timmons (1983) also reported that 1 application of chlorpyrifos was as effective as 2 in controlling infestations of $S$. scitula on flowering dogwoods.

Killing burr knots with NAA will not eliminate an infestation. In fact, the consequences of attack in dead burr knots might be more severe because, for lack of live tissue, larvae will begin to feed in the healthy cambium adjoining the burr knot. In addition, other borer problems may develop. The American plum borer has been observed invading dead burr knots following application of NAA (E. Kuhn, Cooperative Extension, Cornell University, personal communication).

Burr knots can be eliminated altogether by planting deep and avoiding any exposure of the rootstock. In already-planted trees, soil can be placed around the trunk up to the graft union. This can be practicable where the graft union is not too high. The soil should be placed around the trunk in a wide mound and not a narrow cone to avoid winter injury to the covered portion of the trunk ( $R$. Norton, Cooperative Extension, Cornell University, personal communication). The additional root growth from the buried burr knots should improve anchorage and increase tree vigor. However, this may not be desirable in situations where it is important to control vigor and maintain tree size.

\section{Acknowledgments}

We would like to thank Dr. J.G. Franclemont, Department of Entomology, Cornell University, and Dr. T.D. Eichlin, California Department of Food and Agriculture, for identification of sesiid moths. We are also grateful to F. Henrie, W. Henrie, and J. VanKirk for assisting in this investigation. Part of this work was supported by the New York Apple Research Association.

\section{References}

Anonymous. 1980. New York orchard and vineyard survey (New York Crop Reporting Service). 44 pp.

Arnold, C.Y. 1959. The determination and significance of the base temperature in a linear heat unit system. Proc. Am. Soc. Hortic. Sci. 74: 430-445.

Baskerville, G.L., and P. Emin. 1969. Rapid estimation of heat accumulation from maximum and minimum temperatures. Ecology 50: 514-517.

Dickler, E. 1976. Zur Biologie und Schadwirkung von Synanthedon myopaeformis Brkh. (Lepid: Aegeriidae), einem neuen Schaedling in Apfeldichtpflanzungen. Z. ang. Ent. 82: 259-266.

Engelhardt, G.P. 1946. The North American clear-wing moths of the family Aegeriidae. Smithson. Inst., U.S. Natl. Mus. Bull. 190. 222 pp.

Pierce, W.C., and C.B. Nickels. 1941. Control of borers on recently top-worked pecan trees. J. econ. Ent. 34: 522-526.

Pless, C.D., and W.W. Stanley. 1967. Life history and habits of the dogwood borer, Thamnosphecia scitula (Lepidoptera: Aegeriidae) in Tennessee. J. Tenn. Acad. Sci. 42: 117-123.

Potter, D.A., and G.M. Timmons. 1983. Flight phenology of the dogwood borer (Lepidoptera: Sesiidae) and implications for control in Cornus florida L. J. econ. Ent. 76: 1069-1074.

Rom, R.C. 1970. Burr-knot observations on clonal apple rootstocks in Arkansas. Fruit Var. Hort. Dig. 24: 66-68.

Rom, R.C., and S.A. Brown. 1979. Factors affecting burr knot formation on clonal Malus rootstocks. Hort. Sci. 14: 231-232.

Underhill, G.W. 1935. The pecan tree borer in dogwood. J. econ. Ent. 28: 393-396.

Wallace, P.O. 1945. Biology and control of the dogwood borer, Synanthedon scitula Harris. Connecticut Agric. Exp. Stn. Bull. 488: 373-395.

Wiener, L. 1982. Brush away borers. Am. Fruit Grower 102(11): 29.

(Date received: 198412 27; date revision received: 198506 06; date accepted: 19850606 ) 